\title{
Heavy metals interfere with plasma metabolites, including lipids and amino acids, in patients with breast cancer
}

\author{
LING LI $^{1}$, MEIHUA ZHANG ${ }^{2 *}$, YUHAO MEN ${ }^{3}$, \\ WEI WANG ${ }^{1}$ and WEIDONG ZHANG ${ }^{3}$
}

\author{
${ }^{1}$ Department of Oncology; ${ }^{2}$ Medical Image Center, Affiliated Tengzhou Central People's Hospital of \\ Jining Medical University, Tengzhou, Shandong 277599; ${ }^{3}$ College of Animal Sciences and Technology, \\ Qingdao Agricultural University, Qingdao, Shandong 266109, P.R. China
}

Received March 19, 2019; Accepted January 16, 2020

DOI: $10.3892 / 01.2020 .11402$

\begin{abstract}
The aim of the present study was to examine the association between plasma heavy metals and the metabolome in patients with breast cancer (BC), and the association with cancer development. Nuclear magnetic resonance was used to determine the metabolites involved and an inductively coupled plasma mass spectrometry system was used to quantify the heavy metals in the plasma samples. It was indicated that cadmium was significantly higher in the plasma of patients with BC compared with that in the control population $(\sim 15$-fold increase). Chromium, arsenic and lead were also elevated in the plasma of patients with BC by $\sim 3.24,2.14$ and 1.52 fold, respectively. A number of small molecules, including amino acids and salts, were altered in the plasma of patients with $\mathrm{BC}$ compared with the control population. Another notable finding in this investigation was that plasma lipid levels were elevated in patients with BC compared with those in the control population. The findings of the present study suggest that exposure to heavy metals, including cadmium, arsenic, chromium and lead, may influence blood lipid levels and other small molecule metabolites, which in turn may be involved in BC development. Further studies surrounding urinary heavy metals and the metabolome are required to further determine the impact of metals on metabolism and on BC development.
\end{abstract}

\section{Introduction}

Breast cancer (BC) is common in women and is one of the main causes of cancer-associated mortality in the female population worldwide, with an incidence rate of 1 in 8 women (13\%) (1-3). Environmental contamination serves a vital role in cancer

Correspondence to: Dr Meihua Zhang, Medical Image Center, Affiliated Tengzhou Central People's Hospital of Jining Medical University, 181 Xingtan Road, Tengzhou, Shandong 277599, P.R. China

E-mail: tzmeihua@163.com

Key words: breast cancer, heavy metals, metabolome, lipids development, as well as other diseases, including endometrial cancer and endometriosis $(4,5)$. Reports show that $>20 \%$ of global disease burden and $>30 \%$ of disease burden in children is due to contaminated environments $(2,3,5)$. Therefore, it has been speculated that a healthy environment would prevent or decrease the incidence of many diseases/disorders and ultimately reduce morbidity (4). A comprehensive understanding of the mechanisms involved in the etiology of BC and the identification of new biomarkers of its risk are key components for the improvement of BC prevention (6). Even though genetic modifications for $\mathrm{BC}$ have been widely investigated, further advancements are required to uncover the metabolic changes associated with this disease $(7,8)$.

Metabolomics (one of the newest 'omics') is a rapidly developing branch of science and medicine aimed at identifying biomarkers for a number of human diseases or disorders. It has assisted in further understanding the underlying mechanisms of cancers and therefore treatment strategies (9). The pathophysiological status of biological systems can be reflected by changes in the metabolome, which may be owing to genetic alterations in metabolic pathways or changes in catabolism and enzymes activities $(9,10)$. The metabolome is an amplified culmination of biological systems, as small alterations in enzyme activities may result in major changes in metabolite levels (10). Lipids are reported to be risk factors for $\mathrm{BC}$ reoccurrence and development $(11,12)$. Amino acids have also been reported to be associated with BC development $(13,14)$. Nuclear magnetic resonance (NMR) spectroscopy has been extensively used in metabolome studies, due to its ability to detect metabolites in intact tissues and even in in vivo (15). There are many advantages for NMR spectroscopy, such as the following: No need for sample purification; both hydrophilic and hydrophobic metabolites can be detected; quantitative analysis can be performed; a fast method (1-dimensional techniques, excluding solid-state NMR); small amounts of sample are required; a non-invasive and non-destructive method; and high reproducibility (9). Due to the abundance of hydrogen in nature ( $>99.98 \%)$, low relaxation time and an appreciable nuclear spin, proton nuclear $\left({ }^{1} \mathrm{H}\right) \mathrm{NMR}$ is the most popular NMR technique applied in metabolome investigation (16); it can be used to detect metabolomic changes in cells, tissues 
or biofluids $(17,18)$ and to provide novel insights into disease etiology or underlying mechanisms (7,19-21).

The metals chromium $(\mathrm{Cr})$, cobalt $(\mathrm{Co})$, copper $(\mathrm{Cu})$ and nickel (Ni) are important trace elements for humans, since they are components of enzymes. However, at high concentrations the metals can cause serious issues, such as disease or toxicity, owing to their inhibition of enzyme activity (22-25). Some other non-essential heavy metals, such as cadmium $(\mathrm{Cd})$, lead $(\mathrm{Pb})$, mercury $(\mathrm{Hg})$ and tin $(\mathrm{Sn})$, are toxic at high levels, as they can block the functions of other essential metals (26). In addition, in natural conditions these elements cannot be decomposed, or may even be bioaccumulated and biomagnified in food chains $(27,28)$. It has been reported that $\mathrm{Cd}, \mathrm{Cr}$, $\mathrm{Ni}, \mathrm{Cu}, \mathrm{Pb}$ and $\mathrm{Hg}$ are carcinogens $(29,30)$. Furthermore, it has been recorded that $\mathrm{Cd}, \mathrm{Cr}, \mathrm{Ni}, \mathrm{Cu}, \mathrm{Co}, \mathrm{Pb}$ and $\mathrm{Hg}$ can cause lung cancer; $\mathrm{Cr}$ can increase the probability of liver, larynx, esophageal, and gastrointestinal cancer; $\mathrm{Cd}$ and $\mathrm{Ni}$ can result in renal and prostate cancer; $\mathrm{Cu}$ can cause non-Hodgkin's lymphoma or skin cancer; $\mathrm{Pb}$ and $\mathrm{Hg}$ may increase the risk of glioma and stomach, prostate or bladder cancer; and $\mathrm{Ni}$, $\mathrm{Cb}, \mathrm{Hg}, \mathrm{Pb}$ and $\mathrm{Cr}$ (VI) may cause breast sarcoma and carcinoma $(29,30)$. Environmental exposure to heavy metals may be mainly through the food chain, smoking and even drinking water $(31,32)$. Heavy metal anthropogenic contamination comes mainly from power industries, waste deposits and even fertilizers (33).

Some heavy metals, such as $\mathrm{Cd}$, have been found at high levels (20-30 $\mu \mathrm{g} / \mathrm{g}$ tissue) in breast tissue (34). Furthermore, heavy metals can accumulate in breast tissue, cause DNA damage and even increase tumor development (35). However, to the best of our knowledge, the association between plasma heavy metals and the metabolome in patients with $\mathrm{BC}$ is unknown, as is the association between plasma heavy metals and the metabolome in BC development. Therefore, the present investigation aimed to examine the metabolome and heavy metals present in the plasma of patients with $\mathrm{BC}$ at first diagnosis.

\section{Materials and methods}

Patients and plasma sample collection. Plasma samples from female patients with malignant $\mathrm{BC}(\mathrm{n}=105 ; 50.22 \pm 9.83$ years) and age-matched healthy female controls $(n=35$; $49.76 \pm 10.07$ years) were collected from the Affiliated Tengzhou Central People's Hospital of Jining Medical University (Jining, China) between November 2017 and May 2018. Written informed consent was obtained from the patients and controls in the present study. The patients with BC and the control population were from the same local area of Tengzhou. Heavy metal contamination is relatively high in this area owing to the number of mining operations. The study was performed in accordance with the standards of the Institutional Ethical Committee and the Helsinki Declaration of 1975, as revised in 1983, and was approved by the Institutional Review Board of the Affiliated Tengzhou Central People's Hospital of Jining Medical University. The patients were chosen based on the following criteria: i) All patients were female; ii) all patients received positive pathology for $\mathrm{BC}$; iii) all patients were in the early stages of BC (stages I-II), according the clinical Tumor-Node-Metastasis staging method (6,7); iv) no patients received pre-operative treatment, including adjuvant chemotherapy or radiotherapy; and v) patients did not have diabetes or any other diseases. The selected healthy controls included age- and sex-matched healthy subjects with no metabolic diseases and who were confirmed to have no breast lesions following a physical examination followed by mammography and breast ultrasonography. Prior to surgery in the patients and following overnight fasting for all subjects, $10 \mathrm{ml}$ of venous blood was collected from each subject in a vessel tube, containing heparin as the anticoagulant, and was subsequently centrifuged $\left(1,500 \mathrm{x} \mathrm{g}\right.$ for $15 \mathrm{~min}$ at $\left.4^{\circ} \mathrm{C}\right)$ to collect clear plasma. The plasma was then transferred into sterile vials and immediately stored at $-80^{\circ} \mathrm{C}$ until further analysis.

NMR spectroscopy. Nuclear magnetic resonance (NMR) analyses were performed as described previously $(36,37)$. Briefly, prior to the NMR spectroscopy, $200 \mu \mathrm{l}$ of plasma sample was mixed with $80 \mu \mathrm{l}_{2} \mathrm{O}$ solution containing sodium phosphate buffer (0.1 M, pH 7.4) and sodium 3-trimethylsilyl2,2,3,3-d4-propionate as an internal standard ( $\delta=0 \mathrm{ppm})$. The ${ }^{1} \mathrm{H}$ NMR spectra was acquired using a $600.13 \mathrm{MHz}$ Bruker AV600 spectrometer (Bruker Corporation) with a 5-mm CryoProbe at $300 \mathrm{~K}$. Nuclear Overhauser effect spectroscopy and a zg pulse sequence of ${ }^{1} \mathrm{H}$ NMR spectra and zggpr pulse sequence of J-resolved NMR spectra were used to acquire the NMR information (38). The low molecular weight metabolite (LMWM) model and the lipid molecules in lipoprotein particles (LIPO) model were used in this study, as previously described (37). The LIPO model provides information on lipoprotein lipids, and subclasses, which are acquired through the water-suppressed ${ }^{1} \mathrm{H}$ NMR spectrum. Alternately, the LMWM model suppresses most of the broad macromolecules and lipoprotein lipid signals, therefore improving the sensitivity of low molecular weight metabolites (37-41).

NMR spectral processing and analysis. The ${ }^{1} \mathrm{H}$ NMR spectra were processed by MestRe-C software (version 3.0; Mestrelab Research) as described previously $(36,38)$. Briefly, the spectra were binned with a unit of $0.005 \mathrm{ppm}$ between 0.2 and $10.0 \mathrm{ppm}$, and then integrated spectral intensity for each bin. The binned data were adjusted by generalized log transformation and mean-centered prior to multivariate analysis.

Multivariate analyses. The processed NMR datasets were examined by principal component analysis (PCA) and partial least squares discriminant analysis using the SIMCA-P10.0 10.0 software package (MKS Umetrics AB), as previously described $(36,38)$.

Mineral element quantification. Determination of tissue mineral elements was performed as previously described $(42,43)$. Briefly, $0.2 \mathrm{ml}$ aliquots of plasma were transferred to $120-\mathrm{ml}$ Teflon digestion vessels, followed by the addition of $5 \mathrm{ml}$ of nitric acid. Analysis of metals in plasma was preceded by microwave digestion with concentrated nitric acid to destroy organic matter and mineralize the sample. The multi-element calibration standard was provided as $10 \mathrm{mg} / \mathrm{l}$ in 5\% nitric acid and was not in the plasma matrix. An Agilent 7500 (Agilent Technologies, Inc.) inductively coupled plasma mass spectrometry system was used for simultaneous 
determination of $\mathrm{Cd}, \mathrm{Cr}$, Arsenic (As), $\mathrm{Pb}$ and $\mathrm{Hg}$. Positive ionisation mode was used (38). The voltage for the ion lens was set at $6 \mathrm{~V}$; the argon gas flow rate in the spray chamber was $0.88 \mathrm{l} / \mathrm{min}$; the power output for the RF generator was $1,100 \mathrm{~W}$; the auxiliary gas flow rate was $1.2 \mathrm{l} / \mathrm{min}$; and the nebulizer gas flow rate of the plasma was $16 \mathrm{l} / \mathrm{min}$ at room temperature. All the certified reference materials (in solution) were purchased from the National Institute of Metrology. Blank controls $(n=3)$ underwent the same procedures (38).

Statistical analysis. Data were statistically analyzed with SPSS statistics software (version 22; IBM Corp.) and Student's t-test. Differences were compared for every parameter and data are presented as the mean \pm standard deviation. $\mathrm{P}<0.05$ was considered to indicate a statistically significant difference (38).

\section{Results}

Baseline characteristics of the study population. Table I shows the baseline characteristics of the patients with $\mathrm{BC}$ and the control population. There was no significant difference between the mean age of the patients with BC (50.22 \pm 9.83 years) and the control population $(49.76 \pm 10.07$ years). Similarly, there was no significant difference for average body mass index. Following diagnosis with BC at stages I or II, blood samples were drawn from the patients for analysis.

Plasma metabolome changes. The LMWM ${ }^{1} \mathrm{H}$ NMR spectra, the metabolic fingerprints of small molecules, from plasma metabolites of patients with $\mathrm{BC}$ and the control group are presented in Fig. 1A; while the LIPO ${ }^{1} \mathrm{H}$ NMR spectra, the metabolic fingerprints of large molecules, from plasma metabolites of patients with $\mathrm{BC}$ and the control group are presented in Fig. 2A. Chemical shift and peak multiplicity were used to assign the specific plasma metabolite (37-41).

The latent biochemical information from the ${ }^{1} \mathrm{H}$ NMR spectra were analyzed by partial least squares discriminant analysis. For the small molecules in the LMWM model, there was a clear separation between patients with BC and the control population based on score plots (Fig. 1B). For large molecules in the LIPO model, the score plots also indicated a distinct difference between patients with $\mathrm{BC}$ and the control population (Fig. 2B).

Numerous alterations in endogenous metabolites were discovered in the ${ }^{1} \mathrm{H}$ NMR spectra of plasma samples in both the LMWM and LIPO models. Fig. 3 shows the prominent small molecules, whose presence was greater in patients with BC in the LMWM model. Compared with the control population, six metabolites, namely leucine, propylene glycol, citrate, $\beta$-glucose, acetate and phenylalanine, were significantly elevated in patients with BC (Fig. 3). There were seven metabolites, namely arginine, glutamate, trimethylamine, lysine, $\alpha$-glucose, tyrosine and histidine, with significantly decreased levels in patients with BC compared with that in the control group (Fig. 4).

It is noteworthy that the prominent large molecules (lipids or lipoproteins) were different in the LIPO model analysis between patients with $\mathrm{BC}$ and the control population. The levels of all prominent large molecules were increased (Fig. 5). These large molecules were high-density lipoprotein (HDL), HDL
Table I. Baseline characteristics of the study population.

\begin{tabular}{lcc}
\hline Characteristics & $\begin{array}{c}\text { Patients with } \\
\text { BC }(\mathrm{n}=105)\end{array}$ & $\begin{array}{c}\text { Control } \\
\text { group }(\mathrm{n}=35)\end{array}$ \\
\hline Mean age $\pm \mathrm{SD}$, years & $50.22 \pm 9.83$ & $49.76 \pm 10.07$ \\
Mean BMI $\pm \mathrm{SD}, \mathrm{kg} / \mathrm{m}^{2}$ & $24.32 \pm 3.39$ & $24.11 \pm 3.89$ \\
Normal $(18.5-24.9), \mathrm{n}(\%)$ & $67(63.81)$ & $25(71.43)$ \\
Preobese $(25-29.9), \mathrm{n}(\%)$ & $37(35.24)$ & $10(28.57)$ \\
Obesity $(\geq 30), \mathrm{n}(\%)$ & $1(0.95)$ & $0(0.00)$ \\
Stage, $\mathrm{n}(\%)$ & & \\
I & $65(61.90)$ & \\
II & $40(38.10)$ & \\
\hline
\end{tabular}

BMI, body mass index; BC, breast cancer.

low-density lipoprotein (LDL) very low-density lipoprotein (VLDL) $\left(-\mathrm{CH}_{3}\right.$ ), lipid- $\mathrm{CH}_{2}-\mathrm{C}=\mathrm{C}-$, lipid- $\mathrm{C}=\mathrm{C}-\mathrm{CH}_{2}-\mathrm{C}=\mathrm{C}-$ and lipid- $\mathrm{CH}=\mathrm{CH}-$. In addition, $\mathrm{HDL}$ was significantly elevated in patients with $\mathrm{BC}$.

Levels of five heavy metals in the blood. Five common heavy metals (those found at the highest levels in Tengzhou) were measured in the blood samples, including $\mathrm{Cd}, \mathrm{Cr}, \mathrm{As}, \mathrm{Hg}$, and $\mathrm{Hg}$. The five heavy metals in order of relative concentrations $(\mu \mathrm{g} / \mathrm{l})$ from low to high were as follows: $\mathrm{Cd}, \mathrm{Hg}, \mathrm{As}, \mathrm{Pb}$ and $\mathrm{Cr}$. A total of 4 heavy metals, including $\mathrm{As}, \mathrm{Cd}, \mathrm{Cr}$ and $\mathrm{Pb}$, were significantly increased in patients with $\mathrm{BC}$ compared with levels in the control population (Fig. 6). As showed the most significant $\left(\mathrm{P}=2.48 \times 10^{-9}\right)$ increase in patients with $\mathrm{BC}$. Cd showed the greatest increase (14.91 fold) of the metals in patients with BC following by $\mathrm{Cr}$ (3.24 fold), As (2.14 fold) and $\mathrm{Pb}$ (1.52 fold).

\section{Discussion}

$\mathrm{BC}$ is a common type of cancer affecting women worldwide. A number of factors are associated with BC development, including genetic background, diet, lifestyle, obesity, smoking, alcohol consumption and environmental contamination (44-47). Contamination of the local environment serves a vital role in BC development. Environmental metallic compounds have been identified as risk factors for development of BC (48) and a number of heavy metals have been reported to be risk factors for numerous types of cancer, including stomach and liver cancers (49-52). The World Health Organization has classified As, $\mathrm{Cd}$ and $\mathrm{Ni}$ as Group 1 human carcinogens (53). Pb, $\mathrm{Hg}$ and $\mathrm{Cr}$ have been established as human and animal carcinogens or cocarcinogens $(29,30)$. In the present study, it was found that $\mathrm{Cd}$ levels were higher in patients with $\mathrm{BC}$ compared with those in the control population (15 fold); at the same time, $\mathrm{Cr}$, As and $\mathrm{Pb}$ were also elevated in patients with $\mathrm{BC}$ by $3.24,2.14$ and 1.52 fold, respectively. This suggests that these four heavy metals may be involved in BC development. Patients with $\mathrm{BC}$, in addition to the control population, were all situated in a local region area with many mines and where heavy metal environmental contamination has been reported to be high. 
A

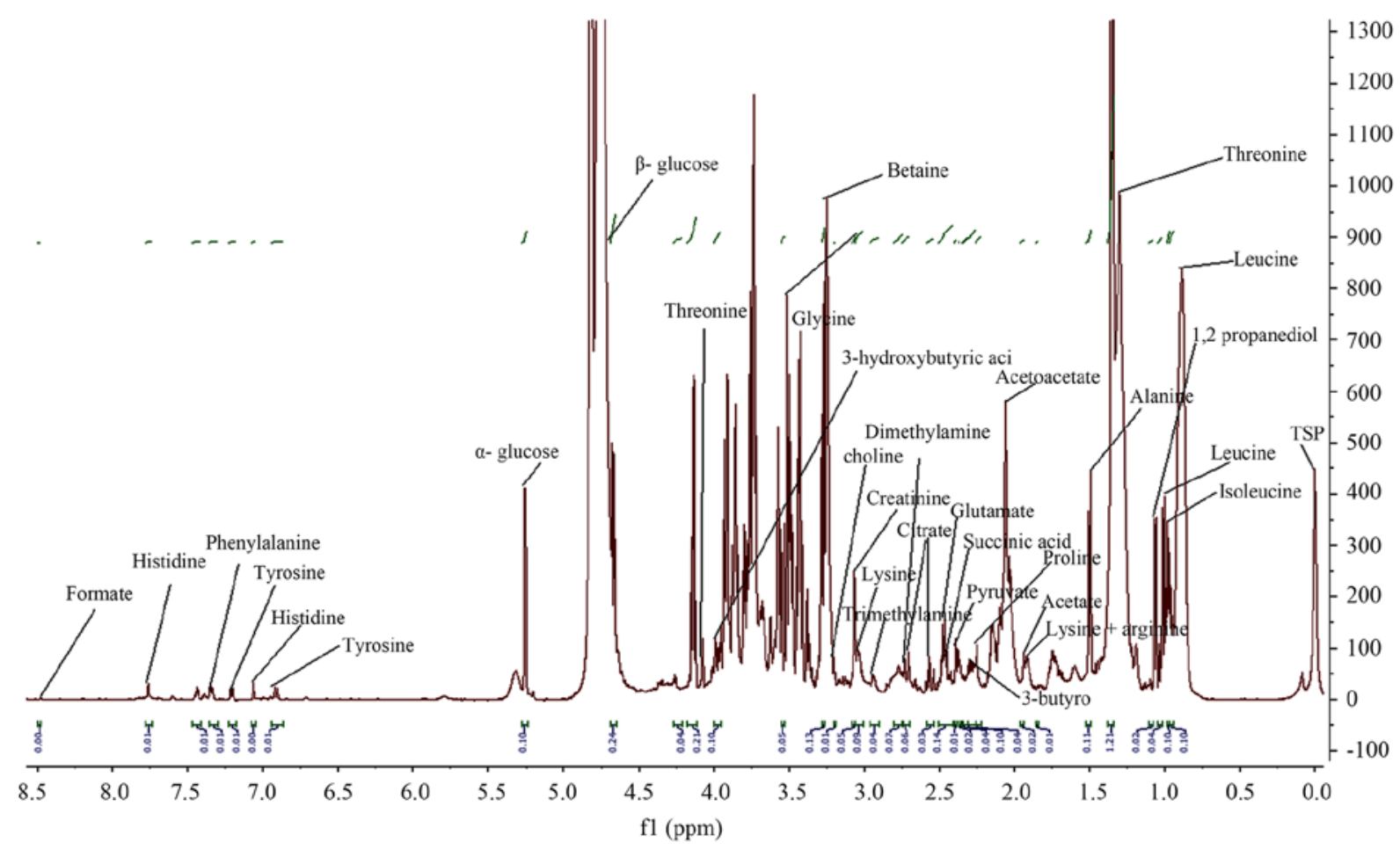

B

Normal $\bigcirc \mathrm{BC}$

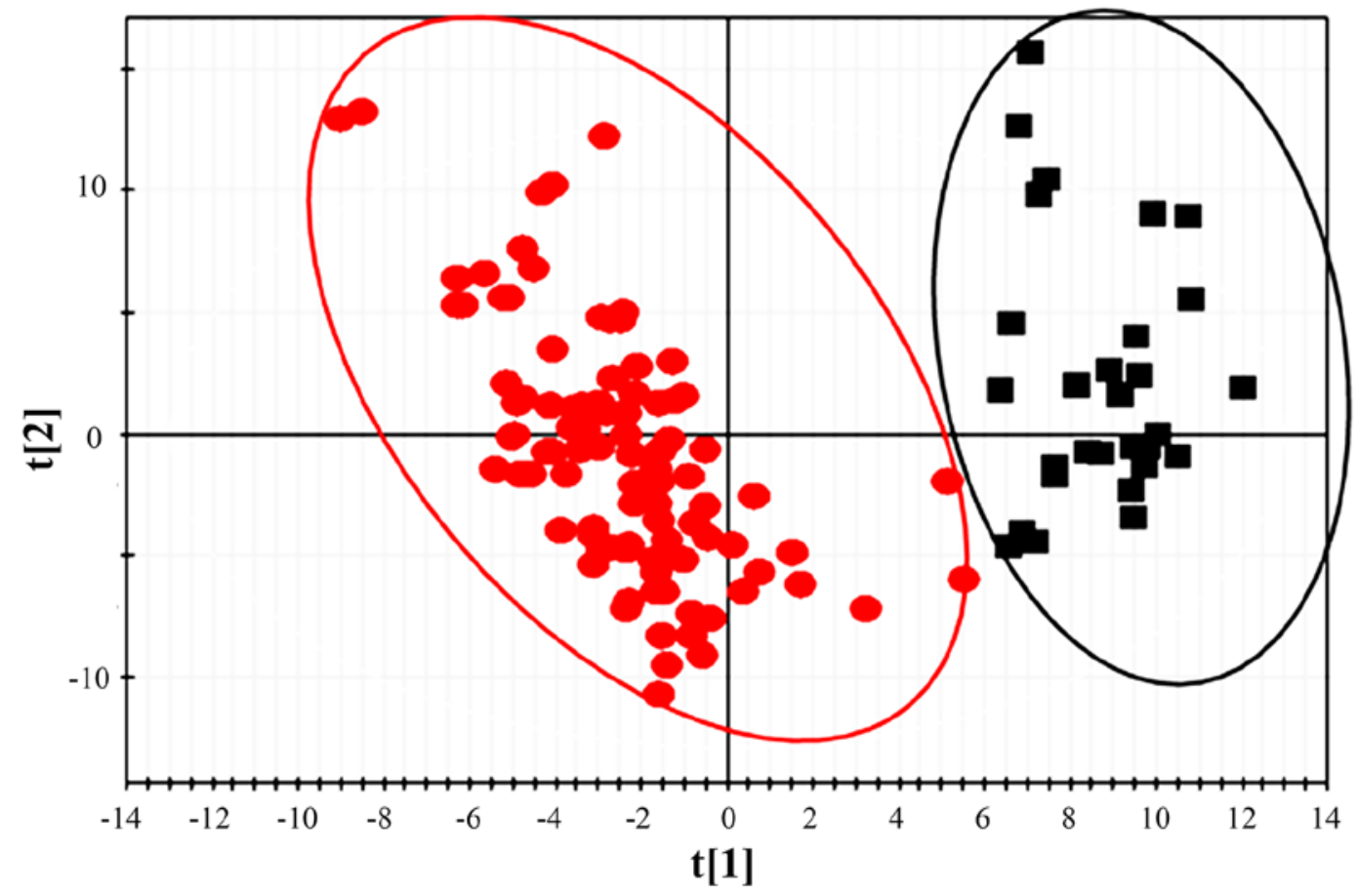

Figure 1. ${ }^{1} \mathrm{H}$ NMR analysis of small molecule metabolites. (A) NMR spectral characteristics and the metabolic contents of the LMWM model analysis. (B) Score plot of the principal component analysis model from the analysis of ${ }^{1} \mathrm{H}$ NMR spectra of plasma for LMWM from patients with BC and the control population. NMR, nuclear magnetic resonance; LMWM, low molecular weight metabolite; BC, breast cancer; TSP, trimethylsilyl propionate.

It has been reported over the last 10 years that heavy metals cause a number of issues, such as immunodeficiency, osteoporosis, neurodegeneration, organ failure and cancer (22). Previous studies have also reported potential associations between heavy metals and estrogen-dependent disorders, including pre-term deliveries, spontaneous abortions, endometrial cancer and BC (22-24). The general population is mainly exposed to heavy metals through environmental contamination. Sources of environmental $\mathrm{Cd}$ exposure to the general population include cigarette smoking, dietary sources and 
A

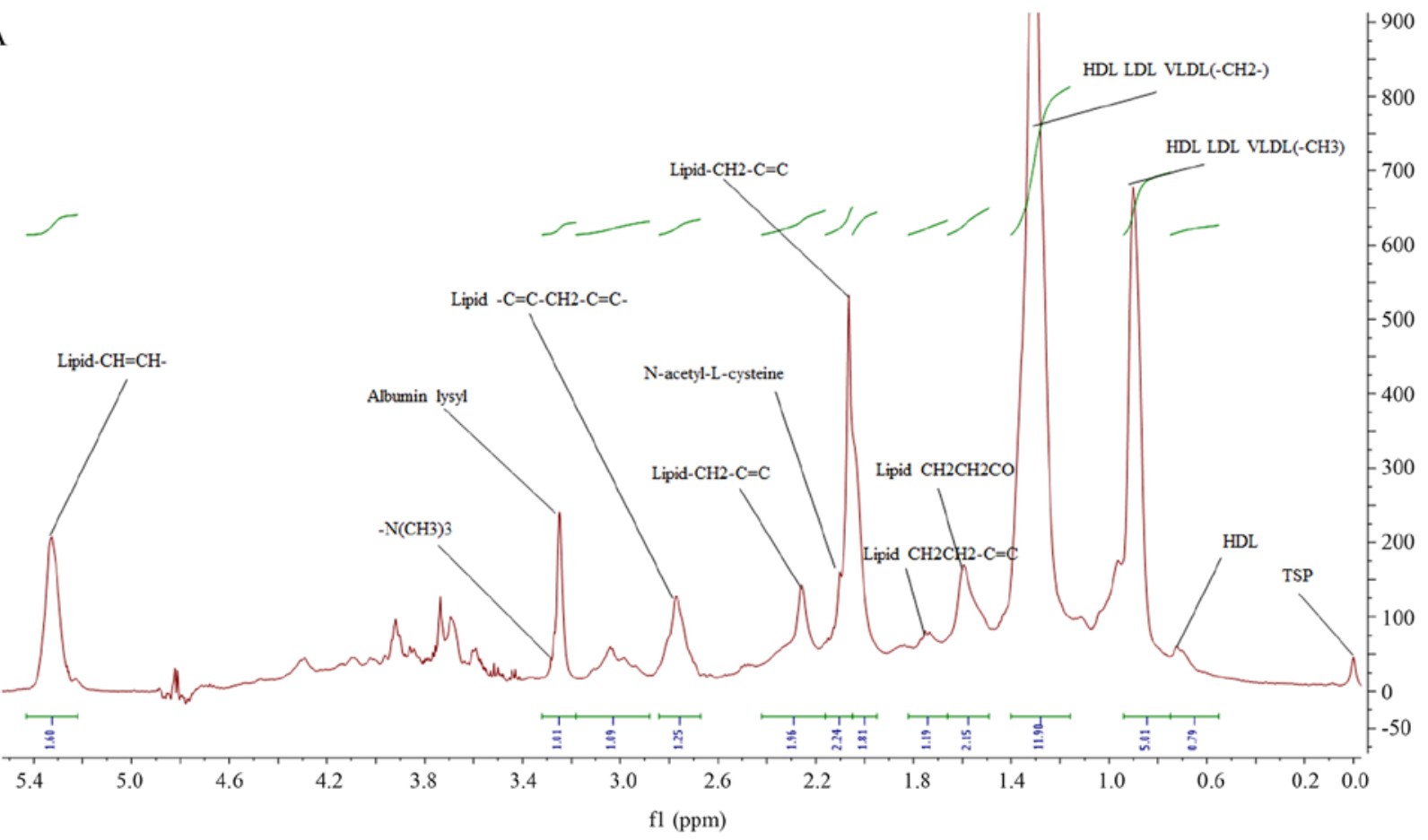

B

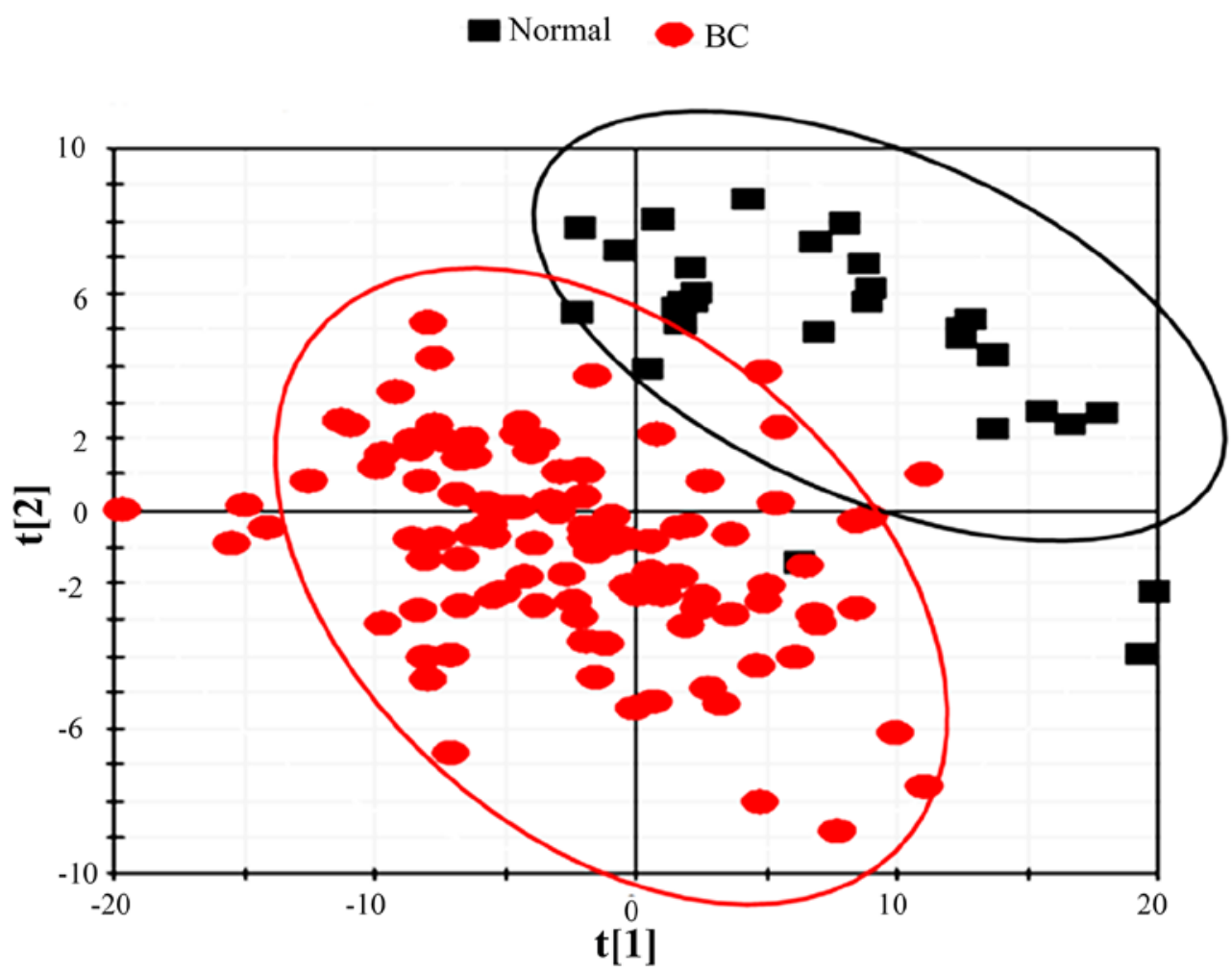

Figure 2. ${ }^{1} \mathrm{H}$ NMR analysis of large molecule metabolites. (A) NMR spectral characteristics and the metabolic contents of the lipoprotein lipid and albumin model analysis. (B) Score plot of the principal component analysis model from the analysis of ${ }^{1} \mathrm{H}$ NMR spectra of plasma for large molecules from patients with $\mathrm{BC}$ and the control population. NMR, nuclear magnetic resonance; BC, breast cancer; HDL, high-density lipoprotein; LIPO, lipid molecules in lipoprotein particles; LDL, low-density lipoprotein; VLDL, very low-density lipoprotein; TSP, trimethylsilyl propionate.

drinking water $(31,32)$. Cd has been found in surface water and even ground water (54). Meanwhile, epidemiological studies have found potential associations linking $\mathrm{Cd}$ exposure and BC development (22-24). It is reported that $\mathrm{Cr}$ exposure is a risk factor for BC development (55). In addition, $\mathrm{Cr}$ has been identified as a potential risk factor for lung cancer, and cancer of the buccal cavity, pharynx, esophagus and NHL, exclusively in women who smoke tobacco, drink Cr-laden water and eat 

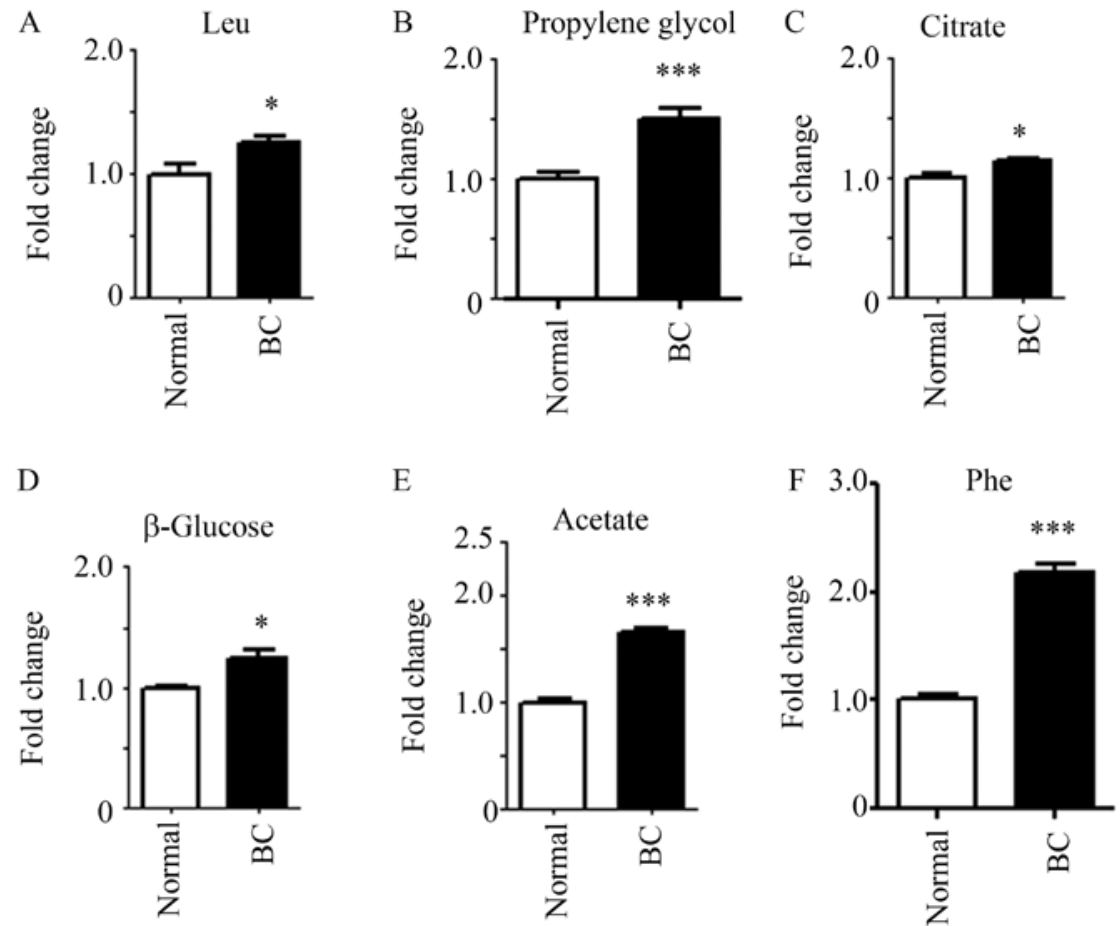

Figure 3. Small molecule metabolites elevated in the plasma of patients with BC. (A) leucine, (B) propylene glycol, (C) citrate, (D) $\beta$-glucose, (E) acetate and (F) phenylalanine in the plasma of patients with $\mathrm{BC}$ and the control population. $\mathrm{n}=35$ for control population; $\mathrm{n}=105$ for patients with $\mathrm{BC}$. ${ }^{*} \mathrm{P}<0.05$ and ${ }^{* * * *} \mathrm{P}<0.001$ vs. normal. BC, breast cancer; Leu, leucine; Phe, phenylalanine.
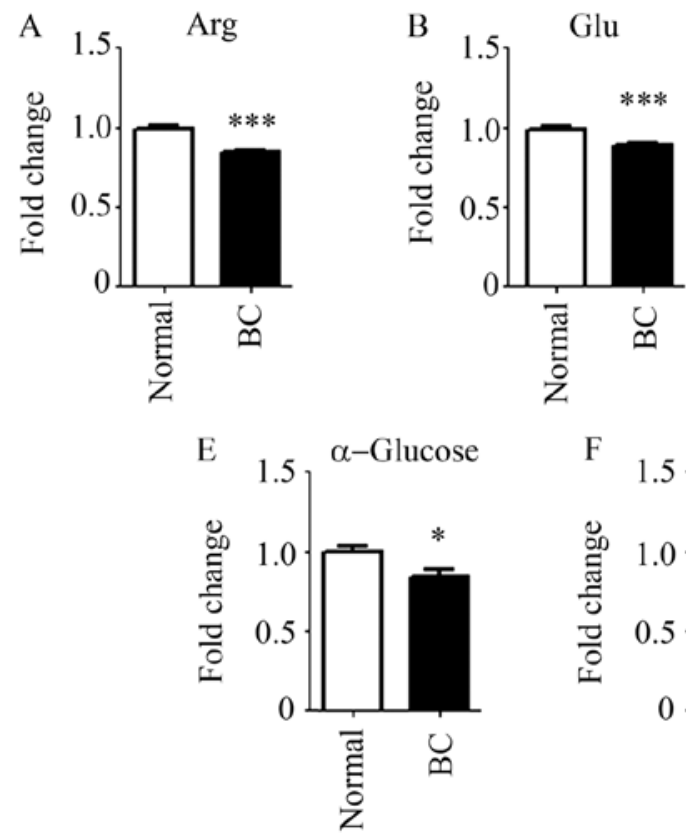

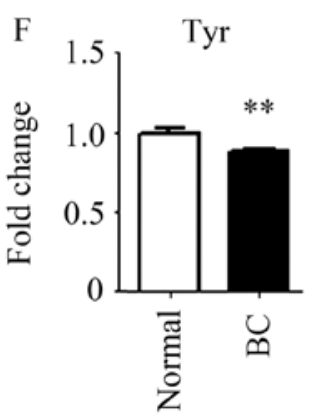

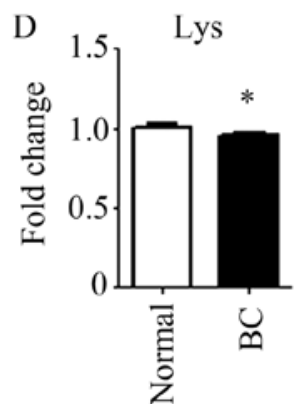

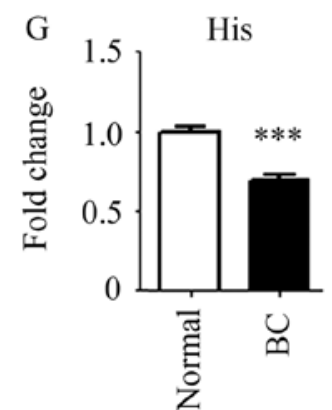

Figure 4. Small molecule metabolites decreased in the plasma of patients with BC. (A) arginine, (B) glutamate, (C) trimethylamine, (D) lysine, (E) $\alpha$-glucose, (F) tyrosine and $(\mathrm{G})$ histidine in the plasma of patients with $\mathrm{BC}$ and the control population. $\mathrm{n}=35$ for control population; $\mathrm{n}=105$ for patients with $\mathrm{BC}$. ${ }^{*} \mathrm{P}<0.05$, ${ }^{* *} \mathrm{P}<0.01$ and ${ }^{* * *} \mathrm{P}<0.001$ vs. normal. BC, breast cancer; Arg, arginine; Glu, glutamate; Lys, lysine; Tyr, tyrosine; His, histidine.

Cr-laden vegetables $(56,57)$. Exposure to As is mainly through food, water and inhalation of sawdust or smoke from burning As-treated materials (58). Exposure of the general population to As is associated with the development of breast, skin, lung, bladder, liver and kidney cancer (54). It has been found that As is a potential risk factor for the development of $\mathrm{BC}$ in patients with the BRCAl gene (33).
Another notable finding in the present study was the elevation of plasma lipids in patients with $\mathrm{BC}$ compared with that in the control population. Usually, lipids are responsible for cardiovascular disease (11). However, more recently it has been discovered that circulating lipids are potential risk factors for BC development $(11,12)$. The cofactors of hyperlipidemia for $\mathrm{BC}$ include a short breastfeeding period and 


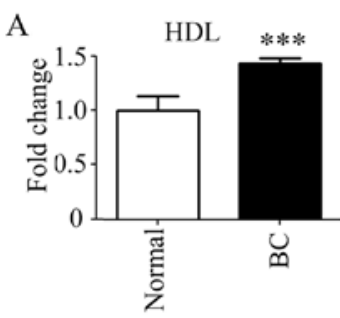

$\mathrm{D}$

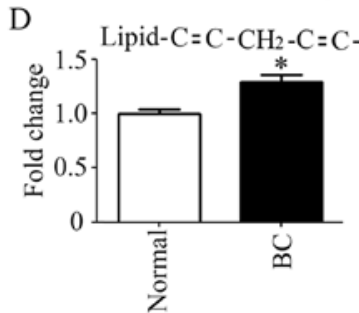

$\mathrm{C}$
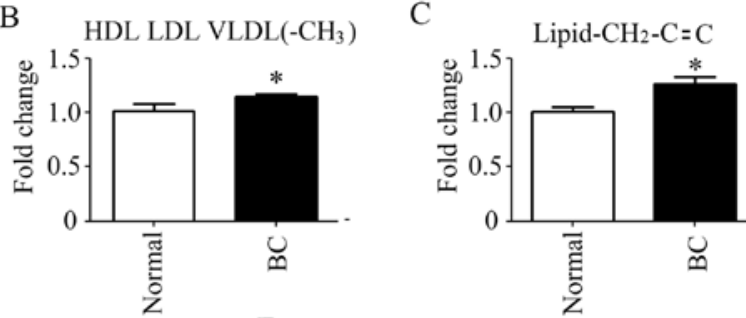

E Lipid- $\mathrm{CH}=\mathrm{CH}-$

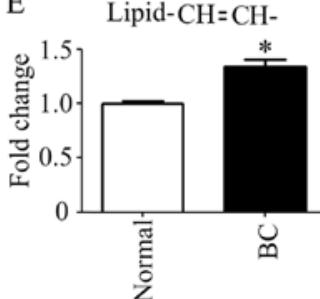

Figure 5. Large molecule metabolites elevated in the plasma of patients with BC. $(\mathrm{A}) \mathrm{HDL},(\mathrm{B}) \mathrm{HDLLDL}$ VLDL $(-\mathrm{CH}),(\mathrm{C}) \mathrm{Lipid}-\mathrm{CH}{ }_{2}-\mathrm{C}=\mathrm{C},(\mathrm{D}) \mathrm{Lipid}-\mathrm{C}=\mathrm{C}-\mathrm{CH} \mathrm{H}_{2}-\mathrm{C}=\mathrm{C}-$ and (E) Lipid- $\mathrm{CH}=\mathrm{CH}$ - in the plasma of patients with $\mathrm{BC}$ and the control population. $\mathrm{n}=35$ for the control population; $\mathrm{n}=105$ for patients with $\mathrm{BC}$. $\mathrm{P}<0.05$ and ${ }^{*} * * * * 0.001$ vs. normal. BC, breast cancer; HDL, high-density lipoprotein; LDL, low-density lipoprotein; VLDL, very low-density lipoprotein.

A

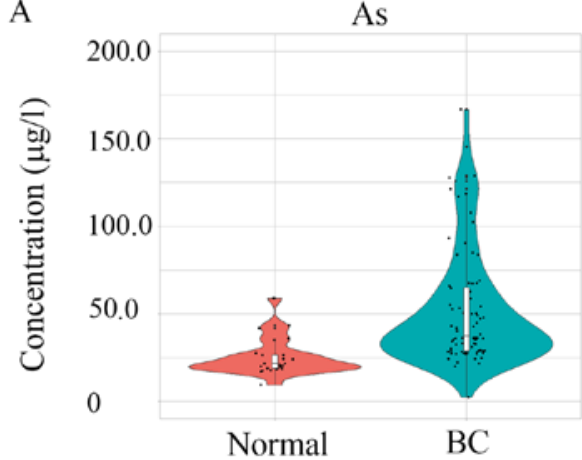

C

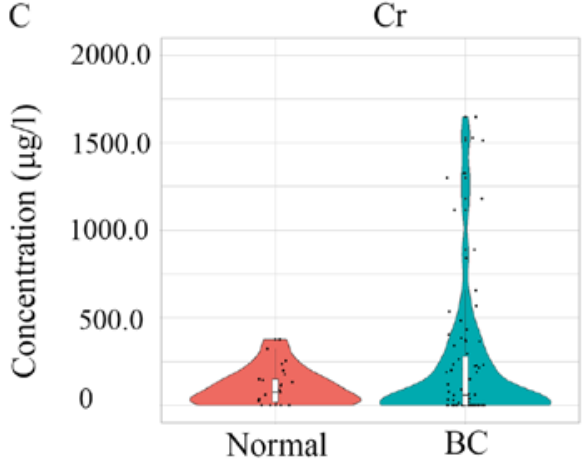

B

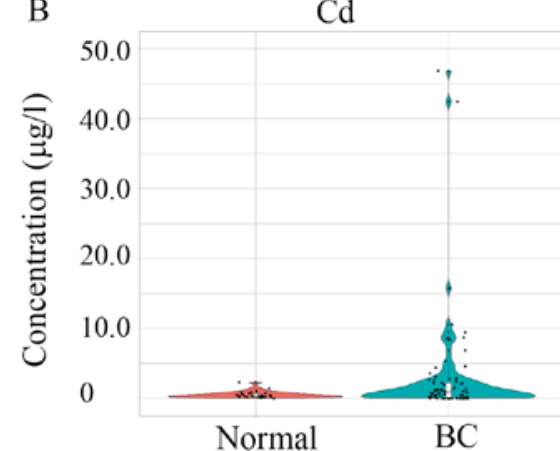

D

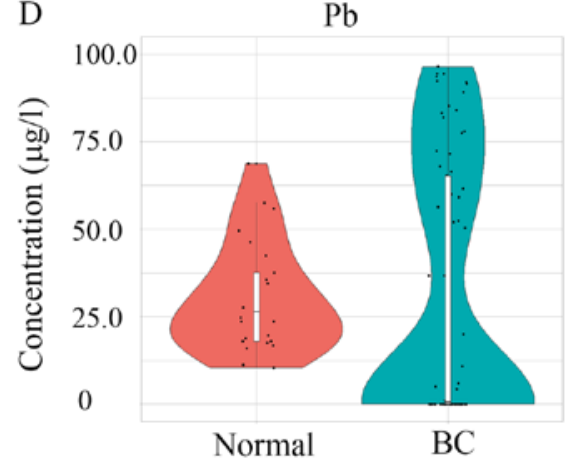

$\mathrm{Hg}$

E

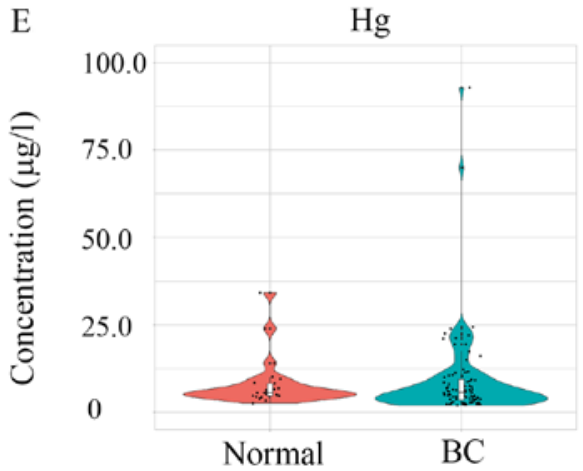

Figure 6. Content of five heavy metals in the plasma of patients with $\mathrm{BC}$ and the control population. (A) $\mathrm{As}$, (B) $\mathrm{Cd}$, (C) $\mathrm{Cr}$, (D) $\mathrm{Pb}$ and (E) $\mathrm{Hg}$ in the plasma of patients with $\mathrm{BC}$ and the control population. $\mathrm{BC}$, breast cancer; $\mathrm{Cd}$, cadmium; $\mathrm{Pb}$, lead; $\mathrm{Hg}$, mercury; As, Arsenic; $\mathrm{Cr}$, chromium. 
mutations in the BRCA1 and BRCA2 genes (59). Furthermore, it has been reported that lipids are the risk factors for $\mathrm{BC}$ reoccurrence. Overall, hyperlipidemia, high serum cholesterol, LDL-cholesterol and triglyceride levels were found to be increased in patients with BC compared with the levels in the control population (60).

Environmental heavy metal exposure serves a vital role in the disturbance of lipid metabolism in humans (61). Elevated blood Cd concentration is reported to be a potential risk factor for dyslipidemia (62). The association of blood $\mathrm{Cd}$ and dyslipidemia is not dependent on lifestyle and BMI (62). Furthermore, blood $\mathrm{Cd}$ was found to be a more valid biomarker for dyslipidemia compared with $\mathrm{Cd}$ in urine (61). Blood $\mathrm{Cd}$ level is not only associated with the increased prevalence of dyslipidemia, but also with the elevated prevalence of high total cholesterol, high triglyceride, high LDL-cholesterol and low HDL-C (62).

Epidemiological studies show that As exposure is associated with cardiovascular diseases, including coronary heart disease and peripheral arterial heart disease $(62,63)$. As can influence the blood concentration of apolipoproteins, which indicates that As may be a potential risk factor for dyslipidemia-associated diseases (63). Another study suggested that As can mediate dyslipidemia and electrolyte retention in rats (64).

The findings of the present study suggest that environmental exposure to heavy metals, such as $\mathrm{Cd}, \mathrm{As}, \mathrm{Cr}$ and $\mathrm{Pb}$, may influence blood lipid levels and other small molecule metabolites, which in turn may be involved in $\mathrm{BC}$ development. However, a limitation of this study was the small population size for both the patients with $\mathrm{BC}$ and the control patients. Further studies to examine urinary heavy metals are required to understand the impact of heavy metals on metabolism and finally on $\mathrm{BC}$ development.

\section{Acknowledgements}

Not applicable.

\section{Funding}

This study was supported by Shandong Province Medical and Health Technology Development Project (grant no. 2016WS0627, Ethic no. 2017- Ethic review-03) and the Supporting Fund for Teachers' research of Jining Medical University (grant no. JY2016KJ041Y, Ethic no. 2017- Ethic review-04).

\section{Availability of data and materials}

All data generated or analyzed during the present study are included in this published article.

\section{Authors' contributions}

LL and MZ provided key intellectual input into the conception and design of the study, and assisted in the writing of the original manuscript. YM and WW performed the experiments. WZ and YM analyzed the data and contributed to the writing of the manuscript. All authors read and approved the final manuscript.

\section{Ethics approval and consent to participate}

The study was performed in accordance to the Institutional Ethical Committee and the Helsinki Declaration of 1975, as revised in 1983, and was approved by the Institutional Review Board of the Affiliated Tengzhou Central People's Hospital of Jining Medical University. Written informed consent was obtained from the patients and controls in the present study.

\section{Patient consent for publication}

Not applicable.

\section{Competing interests}

The authors declare that they have no competing interests.

\section{References}

1. Lécuyer L, Victor Bala A, Deschasaux M, Bouchemal N, Nawfal Triba M, Vasson MP, Rossary A, Demidem A, Galan P, Hercberg S, et al: NMR metabolomics signatures reveal predictive plasma metabolites associated with long-term risk of developing breast cancer. Int J Epidemiol 47: 484-494, 2018.

2. Ferlay J, Soerjomataram I and Ervik M: GLOBOCAN 2012 v1.0, cancer incidence and mortality worldwide: IARC CancerBase No. 11. Lyon, France: International Agency for Research on Cancer, 2013.

3. Siegel R, Naishadham D and Jemal A: Cancer statistics, 2012. CA Cancer J Clin 62: 10-29, 2012.

4. Rzymski P, Tomczyk K, Rzymski P, Poniedziałek B, Opala T and Wilczak M: Impact of heavy metals on the female reproductive system. Ann Agric Environ Med 22: 259-264, 2015.

5. Prüss-Üstün A and Corvalán C: Preventing disease through healthy environments. Towards an estimate of the environmental burden of disease. World Health Organization, France, 2006.

6. Howell A, Anderson AS, Clarke RB, Duffy SW, Evans DG, Garcia-Closas M, Gescher AJ, Key TJ, Saxton JM and Harvie MN: Risk determination and prevention of breast cancer. Breast Cancer Res 16: 446, 2014.

7. Claudino WM, Quattronem A, Biganzoli L, Pestrin M, Bertini I and Di Leo A: Metabolomics: Available results, current research projects in breast cancer, and future applications. J Clin Oncol 25: 2840-2846, 2007.

8. Griffin JL: The Cinderella story of metabolic profiling: Does metabolomics get to go to the functional genomics ball? Philos Trans R Soc London B Biol Sci 361: 147-161, 2006.

9. Kruk J, Doskocz M, Jodłowska E, Zacharzewska A, Łakomiec J, Czaja K and Kujawski J: NMR techniques in metabolomic studies: A quick overview on examples of utilization. Appl Magn Reson 48: 1-21, 2017.

10. Denkert C, Budczies J, Kind T, Weichert W, Tablack P, Sehouli J, Niesporek S, Könsgen D, Dietel M and Fiehn O: Mass spectrometry-based metabolic profiling reveals different metabolite patterns in invasive ovarian carcinomas and ovarian borderline tumors. Cancer Res 66: 10795-10804, 2006.

11. Bathen TF, Sitter B, Sjøbakk TE, Tessem MB and Gribbestad IS: Magnetic resonance metabolomics of intact tissue: A biotechnological tool in cancer diagnostics and treatment evaluation. Cancer Res 70: 6692-6696, 2010.

12. Brennan L: NMR-based metabolomics: From sample preparation to applications in nutrition research. Prog Nucl Magn Reson Spectrosc 83: 42-49, 2014.

13. Dunn WB, Goodacre R, Neyses L and Mamas M: Integration of metabolomics in heart disease and diabetes research: Current achievements and future outlook. Bioanalysis 3: 2205-2222, 2011.

14. Suhre K, Shin SY,Petersen AK, Mohney RP, Meredith D, Wägele B, Altmaier E; CARDIoGRAM, Deloukas P, Erdmann J, et al: Human metabolic individuality in biomedical and pharmaceutical research. Nature 477: 54-60, 2011.

15. Bictash M, Ebbels TM, Chan Q, Loo RL, Yap IK, Brown IJ, de Iorio M, Daviglus ML, Holmes E, Stamler J, et al: Opening up the 'Black Box': Metabolic phenotyping and metabolome-wide association studies in epidemiology. J Clin Epidemiol 63: 970-979, 2010. 
16. Holmes E, Loo RL, Stamler J, Bictash M, Yap IK, Chan Q, Ebbels T, De Iorio M, Brown IJ, Veselkov KA, et al: Human metabolic phenotype diversity and its association with diet and blood pressure. Nature 453: 396-400, 2008.

17. Norvig P, Relman DA, Goldstein DB et al: 2020 visions. Nature 463: 26-32, 2010.

18. Byrne C, Divekar SD, Storchan GB, Parodi DA and Martin MB: Metals and breast cancer. J Mammary Gland Biol Neoplasia 18: 63-73, 2013.

19. Krizek M, Senft V and Motan J: Copper and the human body. Cas Lek Cesk 136: 698-701, 1997 (In Czech).

20. Chan S, Gerson B and Subramaniam S: The role of copper, molybdenum, selenium, and zinc in nutrition and health. Clin Lab Med 18: 673-685, 1998.

21. Christianson DW and Cox JD: Catalysis by metal-activated hydroxide in zinc and manganese metalloenzymes. Annu Rev Biochem 68: 33-57, 1999.

22. Waalkes MP, Fox DA, States JC, Patierno SR and McCabe MJ Jr: Metals and disorders of cell accumulation: Modulation of apoptosis and cell proliferation. Toxicol Sci 56: 255-261, 2000.

23. Järup L: Hazards of heavy metals contamination. Br Med Bull 68: 167-182, 2003.

24. Rzymski P, Niedzielski P, Poniedziałek B and Klimaszyk P: Bioaccumulation of selected metals in bivalves (Unionidae) and Phragmites australis inhabiting a municipal water reservoir. Environ Monit Assess 186: 3199-3212, 2014.

25. Hayes RB: The carcinogenicity of metals in humans. Cancer Causes Control 8: 371-385, 1997.

26. Some metals and metallic compounds. IARC Monogr Eval Carcinog Risk Chem Hum 23: 1-420, 1980.

27. Gartell MJ, Craun JC, Podrebarae DS and Gunderson EL: Pesticides, selected elements and other chemicals in infant and toddler total diet samples. October 1980-March 1982. J Assoc Off Anal Chem 69: 123-145, 1986.

28. Gartell MJ, Craun JC, Podrebarae DS and Gunderson EL: Pesticides, selected elements and other chemicals in adult total diet samples, October 1980-March 1982. J Assoc Off Anal Chem 69: 146-159, 1986

29. Szyczewski P, Siepak P, Niedzielski P and Sobczyński T: Research on heavy metals in Poland. Pol J Environ Stud 8: 755-768, 2009.

30. Antila E, Mussalo-Rauhamaa H, Kantola M, Atroshi F and Westermarck T: Association of cadmium with human breast cancer. Sci Total Environ 186: 251-256, 1996.

31. Romaniuk A,Lyndin M, Moskalenko R, Kuzenko Y, Gladchenko O and Lyndina Y: Pathogenetic mechanisms of heavy metals effect on proapoptotic and proliferative potential of breast cancer. Interv Med Appl Sci 7: 63-67, 2015.

32. Zhang W, Zhao Y, Li F, Li L, Feng Y, Min L, Ma D, Yu S, Liu J, Zhang H, et al: Zinc oxide nanoparticle caused plasma metabolomic perturbations correlate with hepatic steatosis. Front Pharmacol 9: 57, 2018.

33. Soininen P, Kangas AJ, Würtz P, Tukiainen T, Tynkkynen T, Laatikainen R, Järvelin MR, Kähönen M, Lehtimäki T, Viikari J, et al: High-throughput serum NMR metabonomics for cost-effective holistic studies on systemic metabolism. Analyst 134: 1781-1785, 2009.

34. Mäkinen VP, Soininen P, Forsblom C, Parkkonen M, Ingman P, Kaski K, Groop PH; FinnDiane Study Group and Ala-Korpela M: $1 \mathrm{H}$ NMR metabonomics approach to the disease continuum of diabetic complications and premature death. Mol Syst Biol 4: 167, 2008.

35. Yan G, Huang Y, Bu Q, Lv L, Deng P, Zhou J, Wang Y, Yang Y, Liu Q, Cen X and Zhao Y: Zinc oxide nanoparticles cause nephrotoxicity and kidney metabolism alterations in rats. J Environ Sci Health A Tox Hazard Subst Environ Eng 47: 577-588, 2012.

36. Wan Q, He Q, Deng X, Hao F, Tang H and Wang Y: Systemic metabolic responses of broiler chickens and piglets to acute T-2 toxin intravenous exposure. J Agric Food Chem 64: 714-723, 2016.

37. Zhao Y, Feng YN, Li L, Zhang HF, Zhang YN, Zhang PF, Liu XQ, Zhang WD, Huang TT, Zhao L, et al: Tissue-specific regulation of the contents and correlations of mineral elements in hens by zinc oxide nanoparticles. Biol Trace Elem Res 177: 353-366, 2017

38. Men Y, Li L, Zhang F, Kong X, Zhang W, Hao C and Wang G: Evaluation of heavy metals and metabolites in the urine of patients with breast cancer. Oncol Lett 19: 1331-1337, 2020.

39. Zimeri AM, Robb SW, Hassan SM, Hire RR and Davis MB: Assessing heavy metal and PCB exposure from tap water by measuring levels in plasma from sporadic breast cancer patients, a pilot study. Int J Environ Res Public Health 12: 15683-15691, 2015.

40. Wood RY and Della-Monica NR: Psychosocial factors influencing breast cancer risk appraisal among older women. Qual Health Res 21: 783-795, 2011.
41. Salhab M, Bismohun S and Mokbel K: Risk-reducing strategies for women carrying BRCA1/2 mutations with a focus on prophylactic surgery. BMC Womens Health 10: 28, 2010.

42. Jevtic M, Velicki R, Popovic M, Cemerlic-Adjic N, Babovic SS and Velicki L: Dietary influence on breast cancer. J BUON 15: 455-461, 2010

43. Ebrahim AM,Eltayeb MA, Shaat MK, Mohmed NM, Eltayeb EA and Ahmed AY: Study of selected trace elements in cancerous and non-cancerous human breast tissues from Sudanese subjects using instrumental neutron activation analysis. Sci Total Environ 383: 52-58, 2007

44. Florea AM and Büsselberg D: Metals and breast cancer: Risk factors or healing agents? J Toxicol 2011: 159619, 2011.

45. Ilychova SA and Zaridze DG: Cancer mortality among female and male workers occupationally exposed to inorganic lead in the printing industry. Occup Environ Med 69: 87-92, 2012.

46. Qu W, Tokar EJ, Kim AJ, Bell MW and Waalkes MP: Chronic cadmium exposure in vitro causes acquisition of multiple tumor cell characteristics in human pancreatic epithelial cells. Environ Health Perspect 120: 1265-1271, 2012.

47. Cheung MR: Blood lead concentration correlates with all cause, all cancer and lung cancer mortality in adults: A population based study. Asian Pac J Cancer Prev 14: 3105-3108, 2013.

48. Person RJ, Tokar EJ, Xu Y, Orihuela R, Ngalame NN and Waalkes MP: Chronic cadmium exposure in vitro induces cancer cell characteristics in human lung cells. Toxicol Appl Pharmacol 273: 281-288, 2013

49. Wadhwa SK, Kazi TG, Afridi HI, Talpur FN and Naeemullah: Interaction between carcinogenic and anti-carcinogenic trace elements in the scalp hair samples of different types of Pakistani female cancer patients. Clin Chim Acta 439: 178-184, 2015.

50. Núñez O, Fernández-Navarro P, Martín-Méndez I, Bel-Lan A, Locutura JF and López-Abente G: Arsenic and chromium topsoil levels and cancer mortality in Spain. Environ Sci Pollut Res Int 23: 17664-17675, 2016.

51. Welling R, Beaumont JJ, Petersen SJ, Alexeeff GV and Steinmaus C: Chromium VI and stomach cancer: A meta-analysis of the current epidemiological evidence. Occup Environ Med 72: 151-159, 2015.

52. Peralta-Videa JR, Lopez ML, Narayan M, Saupe G and Gardea-Torresdey J: The biochemistry of environmental heavy metal uptake by plants: Implications for the food chain. Int $\mathbf{J}$ Biochem Cell Biol 41: 1665-1677, 2009.

53. ATSDR: Toxicological profile for arsenic. Agency for Toxic Substances and Disease Registry (ATSDR). U.S. Department of Health and Human Services, Atlanta, 2007.

54. IARC Arsenic, metals, fibres and dusts. IARC monographs on the evaluation of carcinogenic risks to humans, vol $100 \mathrm{c}$. International Agency for Research on Cancer, Lyon, 2012.

55. Hasija K and Bagga HK: Alterations of serum cholesterol and serum lipoprotein in breast cancer of women. Indian J Clin Biochem 20: 61-66, 2005.

56. Raza U, Asif MR, Rehman AB and Sheikh A: Hyperlipidemia and hyper glycaemia in breast cancer patients is related to disease stage. Pak J Med Sci 34: 209-214, 2018

57. Laisupasain P. Thompat W, Sukarayodhin S, Somprom A and Sudjaroen Y: Comparison of Serum lipid profiles between normal control and breast cancer patients. J Lab Physician 5: 38-41, 2013.

58. Alexopoulos CG, Blatsios B and Avgerinos A: Serum lipids and lipoprotein disorders in cancer patients. Cancer 60:3065-3070, 1987.

59. Santos-Gallego CG and Jialal I:Cadmium and atherosclerosis: Heavy metal or singing the blues? Atherosclerosis 249: 230-232, 2016.

60. Zhou Z, Lu YH, Pi HF, Gao P, Li M, Zhang L, Pei LP, Mei X, Liu L, Zhao Q, et al: Cadmium exposure is associated with the prevalence of dyslipidemia. Cell Physiol Biochem 40: 633-643, 2016.

61. Ledda C, Iavicoli I, Bracci M, Avola R, Senia P, Santarelli L, Pomara C and Rapisarda V: Serum lipid, lipoprotein and apolipoprotein profiles in workers exposed to low arsenic levels: Lipid profiles and occupational arsenic exposure. Toxicol Lett 282: 49-56, 2018.

62. Waghe P, Sarkar SN, Sarath TS, Kandasamy K, Choudhury S, Gupta P, Harikumar S and Mishra SK: Subchronic arsenic exposure through drinking water alters lipid profile and electrolyte status in rats. Biol Trace Elem Res 176: 350-354, 2017.

63. Cha YJ, Kim ES and Koo JS: Amino acid transporters and glutamine metabolism in breast cancer. Int J Mol Sci 19: E907, 2018.

64. His M, Viallon V, Dossus L, Gicquiau A, Achaintre D, Scalbert A, Ferrari P, Romieu I, Onland-Moret NC, Weiderpass E, et al: Prospective analysis of circulating metabolites and breast cancer in EPIC. BMC Med 17: 178, 2019.

This work is licensed under a Creative Commons Attribution-NonCommercial-NoDerivatives 4.0 International (CC BY-NC-ND 4.0) License. 